\title{
PROFILE IN GANGLIOSIDE ANTIBODIES IN BENIGN PROSTATIC HYPERPLASIA
}

\author{
Ilinca Nicolae ${ }^{1}$, Corina-Daniela Ene ${ }^{2}$, Mirela Petrescu ${ }^{1}$, Simona Roxana Georgescu ${ }^{1}$ \\ ${ }^{1}$ Department Dermatology, "Victor Babes" Clinical Hospital of Tropical and Infectious Diseases, \\ Bucharest, Romania \\ ${ }^{2}$ Nephrology Hospital “Dr. Carol Davila”, Bucharest, Romania
}

\begin{abstract}
Molecular pathology of benign prostatic hyperplasia is multifactorial and involves endocrine, biochemical, immunological interactions. The mechanisms involved in the onset and progression of benign prostatic hyperplasia are: infections, older than 50 years, imbalances in hormones and neurotransmitters, inflammation, oxidative stress. It is estimated that an infectious etiology can be a cause of wrong immune response directed at the prostate. Inflammatory neuropathies often occur after infections with various microorganisms. It is also known, that the presence of microorganisms is heterogeneous in patients with benign prostatic hyperplasia.

In this paper we documented the antibody profile of anti-GM1, -GM2, -GM3, -GD1a, -GD1b, -GT1b, -GQ1b IgG and IgM type in 30 patients with benign prostatic hyperplasia and in 30 controls. The results showed an increasing anti-GD1a and anti-GQ1b titer in patients with benign prostatic hyperplasia compared to control. The authors suggest that a careful monitoring of the patients developing an endogenous anti-gangliosidic immune response is required in order to assess these antibodies as potential risk factors for neuropathy in patients with benign prostatic hyperplasia.
\end{abstract}

Keywords: benign prostatic hyperplasia, infection, gangliosides, anti-gangliosides antibodies, neuropathies

\section{INTRODUCTION}

Benign prostatic hypertrophy is an actual pathology present in older men, affecting their quality of life through extremely troublesome consequences that obstruction or irritation of the lower urinary tract have on the patient. A priority role in the management of patients with prostatic diseases is represented by carefully evaluating and treating urinary tract infections. It is estimated that an infectious etiology can be a cause of a wrong immune response directed at the prostate. Inflammatory neuropathies often occur after infections with various microorganisms. It is also known, that the presence of microorganisms is heterogeneous in patients with benign prostatic hyperplasia.

Gangliosides are oligoglicosilceramides containing one or more sialic acid residues. Numerous studies have shown gangliosides intervention in regulating cellular growth and differentiation, angiogenesis and apoptosis, in immunity, in modulating the receptors of growth factors and in signaling. To symbolize gangliosides Svennerholm classification was adopted. The $\mathrm{G}$ defines the ganglioside. The letters M, D, T, Q symbolizes the number of sialic acids present in the molecule. Number 1, 2, 3, 4 define the nature of the carbohydrate part. A, b, c initials indicate the location of attachment of the second molecule of sialic acid. Gangliosides biosynthesis occurs through the gradual addition of ceramide to oligosaccharides using an complex enzymatic device $(1,2,3,4,5,6)$.

GM1 $=$ Gal-3GalNAc-4(Neu5Ac-3)Gal-4GlcCer; GM2 $=$ GalNAc-4(Neu5Ac-3)Gal-4GlcCer; GM3 = Neu5Ac-3Gal-4GlcCer; 


$$
\begin{aligned}
& \mathrm{GD} 1 \mathrm{a}= \text { Neu5Ac-3Gal-3GalNAc- } \\
& 4(\text { Neu5Ac-3)Gal-4GlcCer; } \\
& \mathrm{GD} 1 \mathrm{~b}= \text { Gal-3GalNAc-4(Neu5Ac-8Neu5Ac-3) } \\
& \text { Gal-4GlcCer; } \\
& \mathrm{GT} 1 \mathrm{~b}= \text { Neu5Ac-3Gal-3GalNAc-4(Neu5Ac- } \\
& \text { 8Neu5Ac-3)Gal-4GlcCer; } \\
& \mathrm{GQ1} 1 \mathrm{~b}= \text { Neu5Ac-8Neu5Ac-3Gal-3GalNAc- } \\
& 4(\text { Neu5Ac-8Neu5Ac-3)Gal-4GlcCer } \\
& \text { Glc }- \text { glucose } ; \text { Gal }- \text { galactose } ; \\
& \text { GalNAc }- \text { N-acetyl-galactosamine. }
\end{aligned}
$$

The possible importance of gangliosides in prostate pathology was investigated in both human and animal models $(5,6,9)$. Comparison of the gangliosidic profile in normal epithelial cells of the prostate, prostatic neoplastic androgen-insensitive cells (PC-3, DU145), neoplastic androgen-sensitive cells ( $\mathrm{LNCaP})$ proved the following: malign epithelial cells express GM1b, GM2, GD2, GD1a, GM3. HH870 and PC3 cells show unique ganglioside components, namely O-acetilGD2 and two GMR17 ganglioside-reactive species (specific antibody for GM1b, GD1a, GT1b) $(5,6)$. In homogenates of tissue from the epithelial cells of the normal prostate (PrEC), androgen-insensitive neoplastic cells (PC-3, DU145) and androgen-sensitive (LNCaP-FGC, LNCaP-FGC-10), GM3, GM2, GD3, GD2 and GD1a were highlighted. In human benign and malign prostatic tissue using $5 \mathrm{~F} 3$ monoclonal antibodies we identified disialosil globopentaosilceramid ganglioside (DSGb5). Antigenic structure of gangliosides could differentiate benign and malignant prostatic tissue $(2,3,5,6)$. A number of studies have evaluated the role of gangliosides in prostate cell growth. The addition of GD3 exogenous culture medium in malignant prostatic cells (PC-3) and normal prostate epithelial cells (RWPE-1) showed a $30 \%$ reduction in the proliferation of malignant cells compared to controls. This ability of exogenous gangliosides to inhibit the spread of prostate cancer could represent a therapeutic benefit in this pathology $(5,6)$.

Less known is the relationship between quantitative changes of extracellular gangliosides, their origin and the progression of prostate disease. Gangliosides may be developed by altered cells, immune and inflammatory cells $(2,3,7,8)$. These gangliosides could induce an antigangliosidic immune response .

Based on these considerations, the interest of authors is focused on profiling the antigangliosidic antibodies in patients with benign prostatic hyperplasia. The objective of this analysis is the investigation of antigangliosidic antibody status as poten- tial risk factors for neuropathy in patients with benign prostatic hyperplasia.

\section{MATERIAL AND METHOD}

In the present study, approved by the Ethics Committee of the Hospital Clinic of Infectious and Tropical Diseases Prof Dr. Victor Babes Bucharest, were included 30 men with benign prostatic hyperplasia (mean age 61 years) and 30 healthy volunteers (average age 58 years) without prostate pathology (control). All study participants gave their consent to the use of biological samples in medical studies without prejudice diagnosis or personal image.

Dosing antigangliosidic antibodies was done by immunoblot technique using human serum (obtained by centrifugation of blood collected in vacutainer without anticoagulant). By this semi-quantitative method we determinated $\operatorname{IgG}$ and $\operatorname{IgM}$ antibodies against seven gangliosides: GM1, GM2, GM3, GD1a, GD1b, GT1b, GQ1b. Identification of the antibodies was made by using marked strips with purified. ganglioside antigens. Evaluation of the obtained results was made using EuroLine Scan software. Interpretation of the results was done according to the cut-off value, determined based on EuroLineScan software signal strength.

\section{STATISTICAL ANALYSIS}

Comparison of quantitative variables for the two groups was performed by $\mathrm{t}$ test. It was chosen as a test of statistical significance $0.05(5 \%), 95 \%$ confidence level showing that the decision is just. Correlations between variables were determined by linear regression and for the presentation of the relationship between two variables Pearson correlation coefficient was used. Data processing was made using SPSS software.

\section{RESULTS}

The ganglioside antibodies model in patients with preoperative benign prostatic hyperplasia will be presented in comparison with the control group. Endogenous immune response against seven gangliosides will be analyzed by IgG and IgM antibodies. Evaluation of the marked strips with GM1 (Table 1), GM2 (Table 2), GM3 (Table 3), GD1a (Table 4), GD1b (Table 5), GT1b (Table 6), GQ1b (Table 7) was done automatically using EuroLineScan software.

In patients with benign prostatic hyperplasia, anti-GM1 IgG antibodies were undetectable in 
$86.6 \%$ of cases with prostatic pathology and $100 \%$ undetectable in control. Anti-GM1 IgM antibodies were absent in $80.0 \%$ of cases with prostate pathology and $100 \%$ of control (Table 1). There were no statistical differences between the two groups $(p=0.372)$.

TABLE 1. Anti-GM1 antibodies in the studied groups

\begin{tabular}{|c|c|c|c|c|}
\hline $\begin{array}{l}\text { EuroLineScan } \\
\text { Signal } \\
\text { intensity }\end{array}$ & Results & $\begin{array}{l}\text { Antibody } \\
\text { Class }\end{array}$ & $\begin{array}{c}\text { Benign } \\
\text { prostatic } \\
\text { hyperplasia }\end{array}$ & Control \\
\hline \multirow{2}{*}{$0-5$} & \multirow{2}{*}{$\begin{array}{c}0 \\
\text { Negative }\end{array}$} & IgG & $26(86.6 \%)$ & $30(100 \%)$ \\
\hline & & $\lg M$ & $24(80.0 \%)$ & 28 (93.3\%) \\
\hline \multirow[t]{2}{*}{$6-10$} & \multirow{2}{*}{$\begin{array}{c}(+) \\
\text { Borderline }\end{array}$} & IgG & 4 (13.4\%) & 0 \\
\hline & & IgM & $6(20 \%)$ & $2(6.7 \%)$ \\
\hline \multirow{2}{*}{$\begin{array}{l}11-25 \text { or } \\
26-50\end{array}$} & \multirow{2}{*}{$\begin{array}{c}+/++ \\
\text { Positive }\end{array}$} & $\operatorname{IgG}$ & 0 & 0 \\
\hline & & IgM & 0 & 0 \\
\hline \multirow{2}{*}{$>50$} & \multirow{2}{*}{$\begin{array}{c}\text { +++ } \\
\text { Intense } \\
\text { positive }\end{array}$} & $\lg G$ & 0 & 0 \\
\hline & & $\operatorname{lgM}$ & 0 & 0 \\
\hline
\end{tabular}

In patients with benign prostatic hyperplasia, GM2 IgG antibodies were undetectable in most cases. Anti-GM1 IgM antibodies were absent in $86.6 \%$ of cases with prostate pathology and $100 \%$ of control (Table 2). There were no statistical differences between the two groups $(p=0.639)$.

TABLE 2. Anti-GM2 antibodies in the studied groups

\begin{tabular}{|c|c|c|c|c|}
\hline $\begin{array}{l}\text { EuroLineScan } \\
\text { Signal } \\
\text { intensity }\end{array}$ & Results & $\begin{array}{l}\text { Antibody } \\
\text { Class }\end{array}$ & $\begin{array}{c}\text { Benign } \\
\text { prostatic } \\
\text { hyperplasia }\end{array}$ & Control \\
\hline \multirow[t]{2}{*}{$0-5$} & \multirow{2}{*}{$\begin{array}{c}0 \\
\text { Negative }\end{array}$} & IgG & 30 (100\%) & $29(96.6 \%)$ \\
\hline & & IgM & $26(86.6 \%)$ & $30(100 \%)$ \\
\hline \multirow{2}{*}{$6-10$} & \multirow{2}{*}{$\begin{array}{c}(+) \\
\text { Borderline }\end{array}$} & $\lg G$ & 0 & 1 (3.4\%) \\
\hline & & IgM & 4 (13.4\%) & 0 \\
\hline \multirow{2}{*}{$\begin{array}{l}11-25 \text { or } \\
26-50\end{array}$} & \multirow{2}{*}{$\begin{array}{c}+/++ \\
\text { Positive }\end{array}$} & IgG & 0 & 0 \\
\hline & & IgM & 0 & 0 \\
\hline \multirow{2}{*}{$>50$} & \multirow{2}{*}{$\begin{array}{c}\stackrel{+++}{ } \\
\text { Intense } \\
\text { positive }\end{array}$} & IgG & 0 & 0 \\
\hline & & $\operatorname{lgM}$ & 0 & 0 \\
\hline
\end{tabular}

The anti-GM3 showed a low intensity of the signal below the cut-off determined by the manufacturer assay kit (signal intensity below 10) (Table 3). There were no statistical differences between the two groups $(\mathrm{p}=0.244)$.

In patients with benign prostatic hyperplasia, positive anti GD1a IgG antibodies were observed in $6.6 \%$ of cases and IgM in $16.6 \%$ of cases (Table $4)$. Between the two groups statistically significant differences were obtained in terms of anti -GD1a antibody model $(\mathrm{p}=0.043)$.
TABLE 3. Anti-GM3 antibodies in the studied groups

\begin{tabular}{|c|c|c|c|c|}
\hline $\begin{array}{l}\text { EuroLineScan } \\
\text { Signal } \\
\text { intensity }\end{array}$ & Results & $\begin{array}{l}\text { Antibody } \\
\text { Class }\end{array}$ & $\begin{array}{c}\text { Benign } \\
\text { prostatic } \\
\text { hyperplasia }\end{array}$ & Control \\
\hline \multirow{2}{*}{$0-5$} & \multirow{2}{*}{$\begin{array}{c}0 \\
\text { Negative }\end{array}$} & $\lg G$ & 23 (76.6\%) & 30 (100\%) \\
\hline & & IgM & $24(80 \%)$ & $30(100 \%)$ \\
\hline \multirow{2}{*}{$6-10$} & \multirow{2}{*}{$\begin{array}{c}(+) \\
\text { Borderline }\end{array}$} & $\lg G$ & $7(23.7 \%)$ & 0 \\
\hline & & IgM & $6(20 \%)$ & 0 \\
\hline \multirow{2}{*}{$\begin{array}{l}11-25 \text { or } \\
26-50\end{array}$} & \multirow{2}{*}{$\begin{array}{c}+/++ \\
\text { Positive }\end{array}$} & $\lg G$ & 0 & 0 \\
\hline & & IgM & 0 & 0 \\
\hline \multirow[b]{2}{*}{$>50$} & \multirow{2}{*}{$\begin{array}{l}\text { +++ } \\
\text { Intense } \\
\text { positive }\end{array}$} & $\lg G$ & 0 & 0 \\
\hline & & $\operatorname{IgM}$ & 0 & 0 \\
\hline
\end{tabular}

TABLE 4. Anti-GD1a antibodies in the studied groups

\begin{tabular}{|c|c|c|c|c|}
\hline $\begin{array}{l}\text { EuroLineScan } \\
\text { Signal } \\
\text { intensity }\end{array}$ & Results & $\begin{array}{l}\text { Antibody } \\
\text { Class }\end{array}$ & $\begin{array}{c}\text { Benign } \\
\text { prostatic } \\
\text { hyperplasia }\end{array}$ & Contro \\
\hline \multirow{2}{*}{$0-5$} & \multirow{2}{*}{$\begin{array}{c}0 \\
\text { Negative }\end{array}$} & IgG & $26(86.7 \%)$ & $30(100 \%)$ \\
\hline & & IgM & $22(73.3 \%)$ & $30(100 \%)$ \\
\hline \multirow{2}{*}{$6-10$} & \multirow{2}{*}{$\stackrel{(+)}{\text { Borderline }}$} & IgG & $2(6.6 \%)$ & 0 \\
\hline & & IgM & $3(10.0 \%)$ & 0 \\
\hline \multirow{2}{*}{$\begin{array}{l}11-25 \text { or } \\
26-50\end{array}$} & \multirow{2}{*}{$\begin{array}{c}+/++ \\
\text { Positive }\end{array}$} & $\lg G$ & $2(6.6 \%)$ & 0 \\
\hline & & $\lg M$ & 5 (16.6\%) & 0 \\
\hline \multirow{2}{*}{$>50$} & \multirow{2}{*}{$\begin{array}{c}\text { +++ } \\
\text { Intense } \\
\text { positive }\end{array}$} & $\lg G$ & 0 & 0 \\
\hline & & IgM & 0 & 0 \\
\hline
\end{tabular}

GD1b antibodies were negative in all studied cases (Table 5). There were no statistical differences between the two groups $(\mathrm{p}=0.984)$.

TABLE 5. Anti-GD1b antibodies in the studied groups

\begin{tabular}{|c|c|c|c|c|}
\hline $\begin{array}{l}\text { EuroLineScan } \\
\text { Signal } \\
\text { intensity }\end{array}$ & Results & $\begin{array}{l}\text { Antibody } \\
\text { Class }\end{array}$ & $\begin{array}{c}\text { Benign } \\
\text { prostatic } \\
\text { hyperplasia }\end{array}$ & Control \\
\hline \multirow{2}{*}{$0-5$} & \multirow{2}{*}{$\begin{array}{c}0 \\
\text { Negative }\end{array}$} & $\lg G$ & $28(93.3 \%)$ & $30(100 \%)$ \\
\hline & & IgM & 30 (100\%) & $30(100 \%)$ \\
\hline \multirow{2}{*}{$6-10$} & \multirow{2}{*}{$\begin{array}{c}(+) \\
\text { Borderline }\end{array}$} & $\lg G$ & $2(6.7 \%)$ & 0 \\
\hline & & IgM & 0 & 0 \\
\hline \multirow{2}{*}{$\begin{array}{l}11-25 \text { or } \\
26-50\end{array}$} & \multirow{2}{*}{$\begin{array}{c}+/++ \\
\text { Positive }\end{array}$} & $\lg G$ & 0 & 0 \\
\hline & & IgM & 0 & 0 \\
\hline \multirow{2}{*}{$>50$} & \multirow{2}{*}{$\begin{array}{c}\text { +++ } \\
\text { Intense } \\
\text { positive }\end{array}$} & $\lg G$ & 0 & 0 \\
\hline & & IgM & 0 & 0 \\
\hline
\end{tabular}

In patients with benign prostatic hyperplasia, GT1b IgG antibodies were undetectable in $96.6 \%$ of each studied group. GT1b antibodie IgM were absent in $93.3 \%$ of cases with prostate pathology and $100 \%$ of control (Table 6 ). There were no statistical differences between the two groups $(p=0.281)$.

In patients with benign prostatic hyperplasia, positive anti- GQ1b IgG antibodies were observed in $20.0 \%$ of cases and $\operatorname{IgM}$ in $23.4 \%$ of cases (Table 7). Between the two groups were obtained statistically significant differences in terms of anti -GQ1b model $(p=0.038)$. 
TABLE 6. Anti-GT1b antibodies in the studied groups

\begin{tabular}{|c|c|c|c|c|}
\hline $\begin{array}{l}\text { EuroLineScan } \\
\text { Signal } \\
\text { intensity }\end{array}$ & Results & $\begin{array}{c}\text { Antibody } \\
\text { Class }\end{array}$ & $\begin{array}{c}\text { Benign } \\
\text { prostatic } \\
\text { hyperplasia }\end{array}$ & Control \\
\hline \multirow[t]{2}{*}{$0-5$} & \multirow{2}{*}{$\begin{array}{c}0 \\
\text { Negative }\end{array}$} & IgG & $29(96.6 \%)$ & $\begin{array}{c}29 \\
(96.6 \%)\end{array}$ \\
\hline & & $\lg M$ & $28(93.3 \%)$ & $30(100 \%)$ \\
\hline \multirow{2}{*}{$6-10$} & \multirow{2}{*}{$\begin{array}{c}(+) \\
\text { Borderline }\end{array}$} & IgG & 0 & $1(3.4 \%)$ \\
\hline & & $\operatorname{lgM}$ & $2(6.7 \%)$ & 0 \\
\hline \multirow{2}{*}{$\begin{array}{l}11-25 \text { or } \\
26-50\end{array}$} & \multirow{2}{*}{$\begin{array}{c}+/++ \\
\text { Positive }\end{array}$} & $\lg G$ & $1(3.4 \%)$ & 0 \\
\hline & & $\operatorname{lgM}$ & 0 & 0 \\
\hline \multirow{2}{*}{$>50$} & \multirow{2}{*}{$\begin{array}{c}\text { +++ } \\
\text { Intense } \\
\text { positive }\end{array}$} & $\lg G$ & 0 & 0 \\
\hline & & $\lg M$ & 0 & 0 \\
\hline
\end{tabular}

TABLE 7. Anti-GQ1b antibodies in the studied groups

\begin{tabular}{|c|c|c|c|c|}
\hline $\begin{array}{l}\text { EuroLineScan } \\
\text { Signal } \\
\text { intensity }\end{array}$ & Results & $\begin{array}{l}\text { Antibody } \\
\text { Class }\end{array}$ & $\begin{array}{c}\text { Benign } \\
\text { prostatic } \\
\text { hyperplasia }\end{array}$ & Control \\
\hline \multirow{2}{*}{$0-5$} & \multirow{2}{*}{$\begin{array}{c}0 \\
\text { Negative }\end{array}$} & IgG & $24(80.0 \%)$ & $30(100 \%)$ \\
\hline & & $\operatorname{lgM}$ & $23(76.6 \%)$ & $30(100 \%)$ \\
\hline \multirow{2}{*}{$6-10$} & \multirow{2}{*}{$\begin{array}{c}(+) \\
\text { Borderline }\end{array}$} & $\lg G$ & $3(10.0 \%)$ & 0 \\
\hline & & IgM & $6(20.0 \%)$ & 0 \\
\hline \multirow{2}{*}{$\begin{array}{l}11-25 \text { or } \\
26-50\end{array}$} & \multirow{2}{*}{$\begin{array}{c}+/++ \\
\text { Positive }\end{array}$} & $\lg G$ & $3(10.0 \%)$ & 0 \\
\hline & & $\operatorname{lgM}$ & $1(3.4 \%)$ & 0 \\
\hline \multirow{2}{*}{$>50$} & \multirow{2}{*}{$\begin{array}{c}\text { +++ } \\
\text { Intense } \\
\text { positive }\end{array}$} & $\lg G$ & 0 & 0 \\
\hline & & $\lg M$ & 0 & 0 \\
\hline
\end{tabular}

\section{DISCUSSIONS}

Humoral immune response in patients with benign prostatic hyperplasia and control, assessed by dosing IgG and IgM type antibodies towards GM1, GM2, GM3, GD1a, GD1b, GT1b, GQ1b is the first study from literature. that:

Based on this analysis, the authors estimated

- in healthy individuals antigangliosidic antibodies IgG and IgM type for all types of the studied gangliosides are absent;

- in patients with benign prostatic hyperplasia positive values were obtained. for anti-GD1a IgG type in $6.6 \%$ of cases and anti-GDla type IgM in $16.6 \%$ of cases

- in patients with benign prostatic hyperplasia it was found an increasing titer of anti-GQ1b IgG type antibodies in $10.0 \%$ and $\operatorname{IgM}$ type in $3.4 \%$ of cases.

Aberrant expression of gangliosides on the surface of prostate cells may induce an endogenous immune response. Developing a unmoral immune response against specific ganglioside could be an important tool for the diagnosis of prostate disease and/or a crucial event in the host protective immunity against a stimulus $(1,2,9,10)$.
Glycosphingolipids characterization and corresponding antibodies in prostate disease is limited. Comparing the antigangliosidic antibody profile endogenous elaborated in control in patients with benign prostatic hyperplasia, prostatic cancer patients in early stages and patients with metastatic prostate cancer, showed qualitative and quantitative changes of IgM antibodies (9).

We analyzed the antibodies profile directed against eight gangliosides: GM1, GM2, GM3, GD1a, GD1b, GD2, GD3, GT1b. The results of this study have shown an increasing titer of anti-GD1a IgM and an reducing titer of anti-GD3 IgM in patients with early prostate cancer than in patients with metastases compared to patients with benign prostatic hyperplasia and compared to controls (9).

These findings suggest that in prostate cancer it can start an endogenous antigangliosidic immune response. IgM titer varies depending on the development stage of prostate cancer. Consequently, multicenter studies are needed to confirm that these antibodies can be used as immunological markers for early detection of prostate cancer. The explanation of this phenomenon is based on the following assumptions (9). First, the synthesis of ceramide mediates apoptosis and tumor cells avoid apoptosis by glycosylation of ceramides and storage of the glycosylated products as sialolactosilceramides or gangliosides in the cytoplasm, or on the outer layer of cell membranes. Secondly, the profile of gangliosides differ qualitatively between normal prostatic epithelial cells, epithelial cells from benign prostatic hyperplasia and malignant prostate epithelial cells. In addition, the cell proliferation is associated with necrosis, which increases the release of gangliosides in the extracellular environment. Fourth, gangliosides exert immunosuppressive effects and induce changes the in immune function. As a result, gangliosides can be recognized as a danger signal by the host immune system.

Hence it can be concluded that the synthesis of IgM antibodies could work as a mechanism to remove these dangerous signals and could restore the immune competence of the host. These data support the role of antiglicosidic antibodies useful as biological markers in differentiating between benign prostatic hyperplasia and prostate cancer.

Likely causes of chronic immune imbalances in benign prostatic hyperplasia may include infections, autoimmune response, urinary reflux, this amylacea corporations. It is estimated that an infectious etiology can be a cause of wrong immune response directed at the prostate $(1,3,5,9,10)$. The emergence of microorganisms is highly heteroge- 
neous in patients with benign prostatic hyperplasia, and viruses were rather observed in prostate cancer pathology.

A new research approach may be represented by identifying the anticlicosidic antibodies directed against gangliosides found in the structure of microorganisms. Antigangliosidic antibodies have been well documented in Campylobacter jejuni infections, cytomegalovirus, Epstein-Barr virus, Mycoplasma pneumoniae, Haemophilus influenzae, Herpes simplex virus, encephalitis virus, B hepatitis virus, human immunodeficiency virus (HIV), rubella, Legionella.

Antigangliosidic antibodies have pathognomonic value for neuropathies $(1,10)$. The explanation of this phenomenon is given based on the ability of antibodies directed against gangliosides found in the structure of the microorganisms to cross-react with gangliosides found in the structure of myelin and nerve fibers, inducing inflammatory processes with consecutive demyelination. These antibodies play a crucial role in Guillain-Barre syndrome, Miller-Fischer, multifocal motor neuropathy, chronic inflammatory demyelinating polyneuropa- thy, chronic neuropathic ataxia, sensory acute ataxic neuropathy, motor axonal neuropathy, acute demyelinating neuropathy in IgM paraproteinemias. Note that the inflammatory neuropathies most often occur after recurrent infections (1). A special attention must be given to molecular alterations in gangliosides metabolism in prostate pathology associated with urinary tract infections. This approach would aim at restoring essential immune competence of the host.

\section{CONCLUSIONS}

Benign prostatic hyperplasia is a common pathology that affects quality of life in older men. The results showed an increasing titer of anti-GQ1b and anti-GD1a in patients with benign prostatic hyperplasia compared to control. The authors suggest that a careful monitoring of the patients developing an endogenous anti-gangliosidic immune response is required in order to assess these antibodies as potential risk factors for neuropathy in patients with benign prostatic hyperplasia.

\section{REFERENCES}

1. Nicolae (Ene) C.D. Rolul unor factori moleculari în aprecierea răspunsului terapeutic la pacienții cu melanom malign cutanat, $\mathrm{PhD}$ thesis. Carol Davila University of Medicine and Pharmacy, Bucharest 2014.

2. Nicolae I. Metabolismul lipidelor in melanom malign. $\mathrm{PhD}$ thesis. University of Bucharest 1998

3. Ene C.D., Nicolae I. Gangliosides and Antigangliosides in Malignant Melanoma in "Melanoma - Current Clinical Management and Future Therapeutics", book edited by Mandi Murph, ISBN 978-953-51-2036-0, Published: 2015.

4. Ene C.D., Penescu M., Anghel A., Neagu M., Budu V., Nicolae. Monitoring Diabetic Nephropathy by Circulating Gangliosides. J Immunoassay Immunochem. 2016; 37(1):68-79.

5. Shimada S., Ito A., Kawasaki Y. Ganglioside disialosyl globopentaosylceramide is an independent predictor of PSA recurrence-free survival following radical prostatectomy. Prostate Cancer Prostate Dis. 2014; 17(2):199-205.

6. Ravindranath M.H., Muthugounder S., Presser N. Gangliosides of organ-confined versus metastatic androgen-receptor-negative prostate cancer. Biochem. Biophys. Res. Commun. 2004; 324(1):154-65.

7. Nicolae I., Nicolae C.D., Coman O.A., Stefanescu M., Coman L., Ardeleanu C. Serum total ganglioside level: clinical prognostic implication. Rom J Morphol Embryol. 2011; 52(4) 1277-1281.

8. Nicolae I., Caragheorgheopol A., Schipor S., Nicolae C., Paun D., Coman O., Benea V. Gangliosides and sex hormones in human melanoma. Acta Endo. 2011; 7(3) 337-344.

9. Ravindranath M.H., Muthugounder S., Presser N. Endogenous immune response to gangliosides in patients with confined prostate cancer. Int. J. Cancer 2015; 116(3):368-77.

10. Nicolae I., Ene C.D., Ceausu E. Investigation on antigangliosides antibodies in asymptomatic HIV patients. BMC Infection Diseases, 2014, 14(suppl4), S4, P25. 